\title{
Osteoporosis in childhood: related factors and prevention
}

\author{
Emilio González-Jiménez, MD¹, Judit Álvarez-Ferre, EnF ${ }^{2}$
}

\section{SUMMARY}

Osteoporosis is defined as a reduction in bone mass. This loss is more important in states of malnutrition, physical inactivity, and with a poor dietary intake of vitamin D and calcium. Bone mineralization depends on both genetic and nutritional factors, as well as endocrine, metabolic, and mechanical factors. Several studies in children have shown that the development of osteoporosis in adulthood may be influenced by the nutritional status during childhood, especially with regard to the contributions of calcium and vitamin D. However, currently there are many questions regarding its pathogenesis and diagnosis and its treatment, some of which are reviewed in this paper. The aim of this work has been to provide an update on the main factors associated with the development of osteoporosis and its prevention in infancy.

Keywords: Osteoporosis; Childhood; Related factors; Prevention.

Colomb Med. 2011; 42: 111-6

\section{Osteoporosis en la infancia: factores relacionados y prevención}

\section{RESUMEN}

La osteoporosis se define como una reducción de la masa ósea. Diversos estudios en niños han demostrado que el desarrollo de osteoporosis en la etapa adulta puede verse condicionado por el estado nutricional durante la infancia, sobre todo en lo referente a los aportes de calcio y vitamina D. No obstante, en la actualidad existen numerosos interrogantes en lo referente a los procesos fisiológicos implicados en su desarrollo precoz en el niño. El objetivo de este trabajo ha sido analizar los principales factores implicados en el desarrollo de la osteoporosis y su prevención en la etapa infantil. Para ello, se realizó una revisión sistemática que incluye un total de 46 artículos publicados en los últimos trece años en Medline. Los estudios analizados coinciden porque consideran que la osteoporosis en el niño representa una manifestación o, mejor, la consecuencia de una situación patológica de base, que condiciona su aparición y desarrollo. Su prevención debe ser considerada en un marco más amplio de estrategias de prevención.

Palabras clave: Osteoporosis; Infancia; Factores de riesgo; Prevención.

Colomb Med. 2011; 42: 111-6

Given the increase in longevity achieved at present, the population has determined a striking increase in the prevalence of certain diseases and, in other cases, the emergence of new forms of illness and during different life stages.

Currently, osteoporosis has become a public health problem predominantly affecting the elderly, demanding an important section of the total health expenditure. On the other hand, it is an important factor in reducing the quality of life of these individuals, preferably by increased risks of fractures ${ }^{1,2}$.

Bone mass and assessment of their status. Bone mass means the total amount of bone tissue in the organism including the ossified extracellular matrix ${ }^{2}$. At present, it is accepted that the acquisition of appropriate peak bone mass is essential to prevent osteoporosis later in life. Since this formation and accumulation of bone mass occurs during the first

1. Professor, Department of Nursing, Faculty of Health Sciences, Universidad de Granada. Granada, España. e-mail: emigoji@ugr.es

2. Nurse, University Hospital «San Rafael», Granada, España. e-mail: jualfe82@gmail.com Received for publication August 30, 2010 Accepted for publication November 23, 2010 


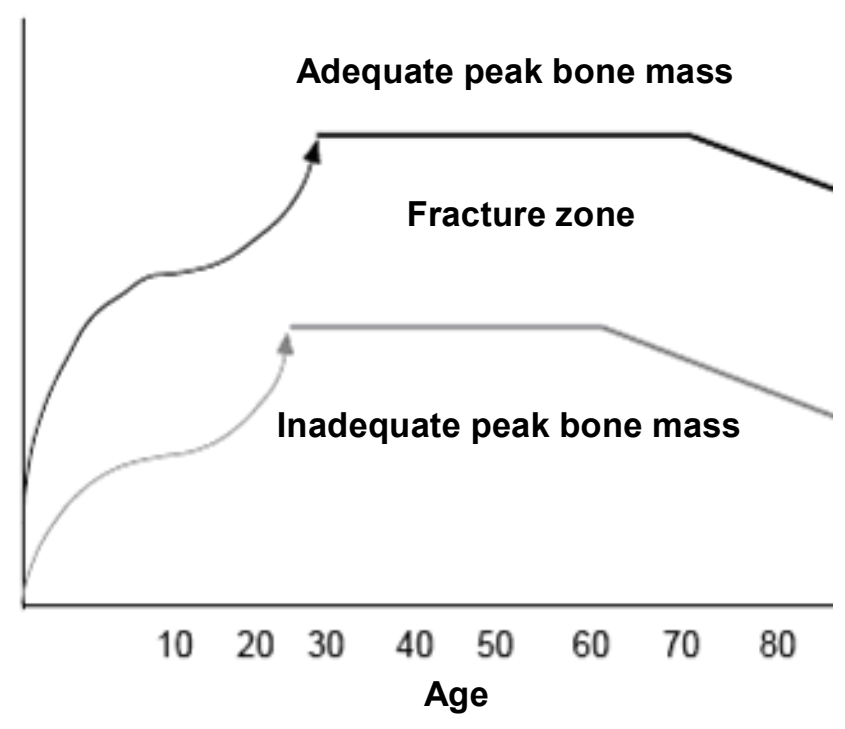

\section{Graphic 1. Obtaining peak bone mass according to age*}

* Taken and adapted from: Alonso F, et al. ${ }^{44}$

decades of life, control of bone mineralization during childhood is a significant aspect to assess interest (Graphic 1). This monitoring should aim at identifying children at risk of developing osteopenia. Also, in the general population, measures should be implemented to prevent the onset of the disease by promoting lifestyles and ways of increasing bone mass ${ }^{3}$.

Achieving an adequate level of bone mass is partly dependent on nutritional factors; therefore, it is necessary to maintain adequate nutrient supplies during the growing stage. Another aspect to consider is genetic factors, accounting for $60 \%$ of the total factors. In adulthood, neo-bone formation decreases after a period in which bone mass remains stable ${ }^{4}$.

Puberty brings the largest increase in bone mineral density in both sexes; however, as in any period changes to diet and exercise may generate as much as $20 \%$ increase ${ }^{5}$. Bone mass is increased from birth to be significantly reduced by calcium deposition as we approach the third decade or so. Up to three years of age, bone mass increases by $30 \%$. It then increases by $20 \%$ and upon reaching puberty there is another $40 \%$ increase. From the end of the growth stage to reaching adulthood there is a $15 \%$ increase in bone mass. Up to 10 years of age, mineralization occurs at the same rate in both sexes. From this age on, mineralization is notably accelerated in girls ${ }^{6}$.

Diagnosis and even preventive and therapeutical evaluation of osteoporosis maybe specially hindered in children because of the need to use techniques that, although sensitive, reproducible, and precise, must be quick, painless, safe and noninvasive.

Of all the methods proposed by the National Osteoporosis Foundation to assess bone quality, the most used technique is dual X-ray absorptiometry (DEXA). The basis of this technique in the attenuation study is subjected to a dual X-ray beam through bone tissue $^{7}$. Although it can be done at different levels, the benchmarks for determining the criteria of normality, osteopenia, or osteoporosis refer to data obtained at the height of the femoral neck or lumbar vertebrae (L2-L4) of the reference population. The interpretation of this technique raises some difficulties in children ${ }^{8}$. There is already benchmarks ${ }^{9-11}$, although obtained from crosssectional studies.

The measurements are available in axial regions (hip, spine) or peripheral regions (calcaneus, tibia, knee, radius and phalanges), although it has been shown that measurements of the spinal column predict risk of fracture at that level, but not others, and the same occurs with the rest of the locations where bone mineral density (BMD) is measured. In children, the area for selection is further complicated because the timing and rate of mineralization depends on the biological age ${ }^{12}$. Sufficiently vascularized bone, with good motility and under some pressure should be selected. In this regard, the determination in the calcaneus could induce excessive bias to withstand pressure, although it is preferred by some authors ${ }^{13}$.

Other recent application techniques are ultrasound imaging and computerized tomography. It is a noninvasive technique, excellently accepted at any age, which has been effective as bone assessment procedures in adults and children ${ }^{14}$. But the excessive costs of computerized tomography limit its use as a technique for the prevention of osteoporosis (Table 1).

Bone mineralization. Bone mineralization is a complex process regulated by genetic and hormonal factors, as well as by environmental and nutritional factors ${ }^{15}$. From a genetic standpoint, mineralization is controlled by a large group of genes. Among the most studied is the gene controlling vitamin D receptor, which depends on calcium absorption in the intestine.

At the hormonal level, there are several hormones involved in bone mineralization. These include para- 
Table 1

Technical features of the measurement of bone mass*

\begin{tabular}{|c|c|c|c|c|c|}
\hline & \multirow[t]{2}{*}{ Techniques } & \multicolumn{2}{|c|}{ Error } & \multirow{2}{*}{$\begin{array}{l}\text { Time } \\
\text { (min) }\end{array}$} & \multirow{2}{*}{$\begin{array}{l}\text { Radiation } \\
\text { (Milirem) }\end{array}$} \\
\hline & & \% Accuracy & $\%$ Accuracy & & \\
\hline \multirow{2}{*}{ Central } & Dexa & $1-2$ & $3-9$ & $5-10$ & $1-5$ \\
\hline & CT scan & $2-4$ & $5-15$ & $10-30$ & 50 \\
\hline \multirow{3}{*}{ Peripheral } & Dexa peripheral & $1-3$ & $3-8$ & $5-15$ & 1 \\
\hline & TC peripheral & $1-2$ & $5-10$ & $5-10$ & 5 \\
\hline & Ultrasound & $2-3$ & & $2-3$ & Nula \\
\hline
\end{tabular}

DEXA: Dual X-ray absorptiometry; CT Scan: Tomography Computed

* Taken and adapted from: Alonso $\mathrm{F}$, et al. ${ }^{44}$

thyroid hormone, which balances the mechanisms of formation and resorption of bone while enhancing vitamin $\mathrm{D}$ action. Calcitonin, which inhibits the action of osteoclasts, and growth hormone, HGH and IGF-1, that acts in the formation of cartilage and promotes the synthesis of the active metabolite of vitamin $\mathrm{D}^{15}$.

Other molecules with activity on bone mass are the corticosteroids. They only act on bone mineralization when increased above normal levels, decreasing bone mass and bone growth. This is an important consideration in children treated with corticosteroids. Thyroid hormones, in turn, are also involved in decreased mineralization with increasing concentrations. But all of these factors may also act on the environmental factors that can intervene by modifying diet and lifestyle ${ }^{15}$.

Osteopenia and osteoporosis. Osteopenia is defined by decreased bone mineral density between -1 and -2.5 SD for age, sex, height, and pubertal stage. Cases where decreased bone mineral density is below 2 SD are considered osteoporosis ${ }^{16}$.

Osteoporosis was defined in 1991 as a systemic skeletal disease characterized by low bone mass and microarchitectural deterioration of bone tissue, which leads to increased bone fragility with a consequent increase in fracture risks. This definition implies a qualitative concept of altered bone architecture and a quantity related to bone density ${ }^{17}$. Both osteoporosis and osteopenia may be primary as in aging or menopause but may also result from inadequate nutrition, and hormonal disorders or diseases of the bone.

However, there are childhood diseases that may be present with osteopenia; thereby, increasing the risk of osteoporosis during adulthood. Manymechanisms could be cited for the production of osteopenia; although, these could be divided into three main groups. One group includes those processes occurring with an inadequate intake of nutrients such as anorexia nervosa, bulimia, protein-calorie malnutrition, or poorly controlled diets ${ }^{18}$. A second group would be composed of those disorders with intestinal malabsorption boxes. Within this section, as possible symptoms of osteopenia generators we could include celiac disease, cystic fibrosis, intolerance to cow milk proteins, and inflammatory bowel disease. Other processes potentially involved in the development of osteopenia include neuropathy and liver disease present with impaired synthesis of active vitamin D metabolites. Other processes involve the states of metabolic acidosis and prolonged administration of certain drugs such as anticonvulsants or corticosteroids ${ }^{19}$.

Nutritional factors. Proper nutrition is a key factor in maintaining adequate skeletal mineralization. In this process of bone mineralization, energy and nutrients intervene in various ways, either by encouraging the development of cell mitosis, participating as visual elements to become vitamin sources, which will involve regulating the synthesis of bone matrix and promoting the absorption level of intestinal calcium or contributing to the synthesis of various hormones and growth factors ${ }^{20}$.

Through feeding, the body receives visual elements; vitamins intervene by regulating the synthesis of bone matrix and intestinal absorption of calcium and other minerals whose primary function is to act on the formation and consolidation of mineralized bone. 
Another essential aspect of bone remodeling in children will be energy intake. This is essential because decreased energy intake induces delays in growth, maturation, and bone mineralization ${ }^{21}$. Then, in children with malnutrition, by default, it is necessary to control the state of bone mineralization.

The bone mineralization process will necessarily be regulated by protein intake through the diet. In this sense, in children, situations of inadequate intake may induce the emergence of problems of mineralization. On the contrary, when its contribution in the diet is excessive it can cause hypercalciuria boxes; this is due to increased excretion of acid produced during protein catabolism. At present, it is possible that the protein diet consumed in most developed countries is closely linked to increased osteoporosis in the population ${ }^{22}$.

Another aspect to consider is the ratio of sodium ingested to calcium excreted by the kidney. Sodium and calcium share the same carrier at the proximal renal tubule. There is yet no need to adjust the contribution of calcium to sodium intake through the diet in children ${ }^{23}$.

Physical exercise, for its part, plays an important role in bone remodeling, especially weight-bearing exercise, i.e., one that creates pressure on the skeleton. In this sense, running would be one of the physical activities that would increase bone mass development to a greater degree. Moreover, at present it is unknown whether the amount of calcium ingested in the diet may or may not alter the beneficial effect of exercise ${ }^{24,25}$.

Calcium. Calcium is an essential pillar in the prevention of osteoporosis. In our body and especially in the bones, it is deposited as hydroxyapatite crystals. Its deposit varies throughout life from 30 grams at birth to about 1300 grams in adulthood ${ }^{26}$. Given this, it will be necessary to modulate calcium intake during periods of increased growth and, especially during adolescence. Adolescence tends to accumulate $40 \%$ of the total bone mass produced throughout life. Several studies have shown that calcium supplementation during adolescence increases bone mineral density ${ }^{26}$. Administering 500 $\mathrm{ml}$ of milk per day during childhood will ensure intake of about $400 \mathrm{mg}$ of calcium, equivalent to $60 \%$ of the recommended daily amount.

Moreover, we have to take into account the bioavailability of calcium in food. The presence of phytates inhibits absorption and, therefore, vegetables, legumes, and cereals despite containing high levels of calcium are not as comparable as milk. Similarly, oxalates, alcohol, caffeine, and phosphates hinder calcium absorption even when present in the $\operatorname{diet}^{27,28}$. Finally, obesity and overweight conditions in children have been associated with increased bone density; nevertheless, there is evidence linking these situations to a higher incidence of fractures ${ }^{29}$.

Appropriate strategies to prevent osteoporosis from childhood. To prevent osteoporosis, it is necessarily to have an assessment of bone mineralization status from early infancy, particularly in subjects at risk. In this sense, preterm infants, patients with malabsorption syndromes, and corticosteroid therapy patients constitute the population at greatest risk of poor bone mineralization $^{30,31}$.

The bioavailability of calcium in maternal milk is far superior to commercial formulas, making it the leading source for calcium during breastfeeding. Only in the case of infants should calcium intake be increased to the recommended supplementary levels using commercial formulas with higher calcium contents ${ }^{32}$.

In children one to eight years of age, there is no explicit consensus on the specific requirements for calcium. In any case, we recommend an intake of $500 \mathrm{mg}$ per day for one- to three-year olds ${ }^{33}$. This figure should be increased as they age and approach puberty. Thus, for those four to eight years of age, the requirements will amount to 800 $\mathrm{mg}$ of calcium per day. But overt health benefits by increasing the daily amount have not been found ${ }^{34}$. And at puberty, it is estimated that for every inch of growth, $20 \mathrm{~g}$ of calcium are required ${ }^{34,35}$.

It is estimated that the highest positive balance is achieved with an average daily intake of $1300 \mathrm{mg}$. In contrast, those exposed to lower levels will have a negative impact on the bone mineralization process ${ }^{36}$. This corresponds to measurements made on white teens ${ }^{37}$.

Excess calcium in the diet, in turn, can cause a deficiency of iron and zinc, while favoring the formation of kidney stones ${ }^{26}$. Similarly, phosphates present in carbonated drinks can also act by inhibiting the absorption of calcium in the intestine ${ }^{26}$.

In cases of subjects with lactose intolerance, the simple addition of commercial lactase or ingestion of fermented dairy products like yogurt can remedy this situation $^{38}$.

Finally, toxic habits such as snuff or alcohol may 
also interfere with bone mineralization ${ }^{39}$. But if there is a successful strategy to prevent osteoporosis from childhood, it is regular physical exercise ${ }^{40,41}$. Physical exercise from an early age not only guarantees us an optimal weight status, but also formidable skeleton mineralization of our circumstances is of great importance when the subject population is children and teenagers ${ }^{42-44}$.

\section{REFERENCES}

1. National Institute of Health. Osteoporosis and related bone diseases. [fecha de acceso: 16 de diciembre de 2010]. National Resources Center. URL: www.osteo.org

2. González Jiménez E, Álvarez Ferre J, Pozo Cano MD, Navaro Jiménez MC, Aguilar Cordero MJ, Tristán Fernández JM. Osteoporosis involutiva tipo I en la mujer posmenopáusica: diagnóstico y manejo clínico. REEMO. 2009; 18: 77-84.

3. Sluis IM, Muinck K. Osteoporosis in childhood: bone density of children in health and disease. JPediatr Endocrinol Metabol. $2001 ; 14: 817$.

4. Lonzer MD, Imrie R, Rogers D, Worley D, Licata A, Secie M. Effects of heredity, age, weight, puberty and calcium intake on bone mineral density in children. Clin Pediatr. (Philadelphia) 1996; 35: 185.

5. Ballabriga A, Carrascosa A (eds). Masa ósea y nutrición en nutrición en la infancia y adolescencia. $3^{\mathrm{a}} \mathrm{ed}$. Madrid: Ergon; 2006.

6. Gil Campos M. Nutrición y salud ósea en la infancia y la adolescencia En: Díaz Curiel M, Gil Hernández A, Mataix Verdú J (eds.). Nutrición y salud ósea. Puleva: Granada; 2004.

7. National Osteoporosis Foundation. Review of the evidence for prevention, diagnosis and treatment, and cost-effectiveness analysis. Osteoporosis Int. 1998; 8: 1-88.

8. Gilsanz V. Bone density in children: A review of the available techniques and indications. Eur J Radiol. 1998; 26: 177-82.

9. Yeste D, Del Río L, Carrascosa A. Valores de contenido mineral óseo, densidad mineral ósea y densidad mineral ósea volumétrica en niños y adolescentes. En: Argente J, Carrascosa A, Gracia R, Rodríguez F (eds.) Tratado de endocrinología de la infancia y adolescencia. Barcelona: Doyma; 2000. p. 1501-12.

10. Carrascosa A, Ballabriga A. Patrones de crecimiento y composición corporal. En: Ballabriga A, Carrascosa A (eds.) Nutrición en la infancia y adolescencia. $3^{\mathrm{a}}$ ed. Madrid: Ergon; 2006. p. 1289-319.

11. Carrascosa A. Masa ósea y nutrición. En: Ballabriga A, Carrascosa A (eds.) Nutrición en la infancia y adolescencia. $3^{\mathrm{a}}$ ed. Madrid: Ergon; 2006. p. 919-49.

12. Bos S, Delmas PD, Pearce D. The differing tempo of grow thin bone size, mass and density in girls is region specific. J Clin Invest. 1999; 104: 795-804.

13. Gregg EW, Kriska AM, Salamone LM. The epidemiology of quantitative ultrasound: Are view of the relationship with bone mass, osteoporosis and fracture risk. Osteoporos Int. 1977; 7: 89-99.

14. Polanco I, Hernández J, Scherer JI, Prieto G, Molina M, Sarria J. Curva de normalidad en población española de 4 a 22 años para un densitómetro óseo por ultrasonidos DBM Sonic 1200. Pediatrika. 2000; 20: 55-64.

15. Alonso Franch M, Redondo del Río MP. Nutrición y patología ósea en la infancia. En: Gil Hernández A (ed.). Tratado de nutrición. Madrid: Acción Médica; 2005.

16. Creer FR, Krebs NF. Comité on nutrition, optimizing bone health and calcium intakes of infants, children and adolescents. Pediatrics. 2006; 117: 578.

17. Morris RC, Frassetto LA, Schmidlin O, Forman A, Sebastián A. Expression of osteoporosis as determined by diet-disordered electrolyte and acid-base metabolism. In: Burckhardt P, Dawson-Hugues B, Heaney RP (eds.). Nutrtional aspects of osteoporosis. San Diego: CA Academic Press; 2001.

18. Winzenberg TM, Oldenburg B, Frendin S, De Wit L, Jones G. A mother-based intervention trial for osteoporosis prevention in children. Prev Med. 2006; 42: 21.

19. Welten DC, Kemper HC, Post GB, Van Mechelen W, Twisk $\mathrm{J}$, Lips P. Weight-bearing activity during youth is a more important factor for peak bone mass than calcium intake. $J$ Bone Miner Res. 1994; 9: 1089-96.

20. Weaver CM, Hauney RP, Prouly WR. Choices for achieving adequate dietary calcium with a vegetarian diet. Am J Clin Nutr. 1999; 70: 534-8.

21. Stalling VA. Calcium and bone health in children: a review. Am J Ther. 1997; 4: 259.

22. Bishop NJ, King FJ, Lucas A. Increased bone mineral content of preterm infants fed with a nutrient enriched formula after discharge from hospital. Arch Dis Child. 1993; 68: 573.

23. Hernández Rodríguez M. Alimentación y problemas nutricionales en la adolescencia. En: Alimentación infantil. $2^{a}$ ed. Madrid: Díaz de Santos; 1993.

24. Bryant RJ,Wastney ME, Martin BR,Wood O, McCabe GP, Morshidi M, et al. Racial differences in bone turnover and calcium metabolism in adolescent females. JClin Endocrinol Metab. 2003; 88: 1043.

25. Loud KJ, Gordon CM. Adolescence: bone disease. En: Walker WA, Duggan C (eds.) Nutrition in pediatrics. Basic science and clinical applications. $3^{\text {rd }}$ ed. Ontario: Decker Inc; 2003.

26. Díaz M, Riobo P, Esteban J, Rodríguez G. Nutrición en las enfermedades del tejido conectivo y del sistema óseo en el adulto. En: Gil A (ed.). Tratado de nutrición. Tomo III. Madrid: Acción Médica; 2005. p.1019-36.

27. Fernández I, Alobera MA, Del Canto M, Blanco L. Physiological bases of bone regeneration II. The remodeling process. Med Oral Pathol Oral Cir Bucal. 2006; 11: E151-7.

28. Krall EA, Dawson-Hughes B. Osteoporosis. En: Shils ME, Olson JA, Ross AC (eds.). Nutricion en salud y enfermedad. México: Interamericana. p. 1563-76.

29. Huth PJ, Dirienzo DB, Miller GD. Major scientific advances with dairy foods in nutrition and health. J Dairy Sci. 2006; 89: 1207-221.

30. Hathcock JN, Shao A, Vieth R, Heaney R. Risk assessment for vitamin D. Am J Clin Nutr. 2007; 85: 6-18. 
31. Papierska L, Rabijewski M. Glucocorticoid induced osteoporosis. Pol Arch Med Wewn. 2007; 117: 363-9.

32. Guéguen L, Pointillart A. The bioavailability of dietary calcium. J Am Coll Nutr. 2000; 19: 119-36.

33. Food and Nutrition Board, Institute of Medicine. Dietary reference intakes for arsenic, boron, calcium, chromium, copper, fluoride, ioride, iron, magnesium, manganese, molybdenum, nickel, phosphorus, selenium, silicon, vanadium and zinc. Washington, DC: National Academy Press; 2004. p. 290-393.

34. Stevenson JC. Pathogenesis, prevention, and treatment of osteoporosis. Obstet Gynecol. 1990; 75 (Suppl): 36-41.

35. Krassas GE. Idiopathic juvenile osteoporosis. Ann N Y Acad Sci. 2000; 900: 409-12.

36. Smith R. Idiopathic juvenile osteoporosis: Experience of twenty-one patients. Br J Rheumatol. 1995; 34: 68-77.

37. Bacciottini L, Brandi ML. Foods and new foods: the role of nutrition in skeletal health. J Clin Gastroenterol. 2004; 38: $115-7$.

38. Ahmed SF, Elmantaser M. Secondary osteoporosis. Endocr Dev. 2009; 16: 170-90.

39. Nikander R, Sievänen H, Heinonen A, Daly RM, Uusi-Rasi K,
Kannus P. Targeted exercise against osteoporosis: A systematic review and meta-analysis for optimising bone strength throughout life. BMC Med. 2006; 21: 1-16.

40. Macdonald HM, Cooper DM, McKay HA. Anterior-posterior bending strength at the tibial shaft increases with physical activity in boys: evidence for non-uniform geometric adaptation. Osteoporos Int. 2009; 20: 61-70.

41. Macdonald HM, Kontulainen SA, Khan KM, McKay HA. Is a school-based physical activity intervention effective for increasing tibial bone strength in boys and girls? JBone Miner Res. 2007; 22: 434-46.

42. Weeks BK, Young CM, Beck BR. Eight months of regular inschool dumping improves indices of bone strength in adolescent boys and Girls: the POWER PE study. J Bone Miner Res. 2008; 23: 1002-11.

43. Vainionpaa A, Korpelainen R, Sievanen H, Vihriala E, Leppaluoto J, Jamsa T. Effect of impact exercise and its intensity on bone geometry at weightbearing tibia and femur. Bone. 2007; 40: 604-11.

44. Alonso Franch M, Redondo Del Río MP, Suárez Cortina L. Nutrición infantil y salud ósea. An Pediatr. (Barc) 2010; 72: $1-11$. 